\title{
Impact of Physical Form of Linseed on Digestibility, Rumen Fermentation and Milk Yield of Dairy Cow
}

Haiam A. Sayed ; A.SH.E. Shams; M.H. H. Kandial and Shahera. M. El-Ganini

Animal Produc. Research Institute, Ministry of Agric., Dokki, Giza, Egypt

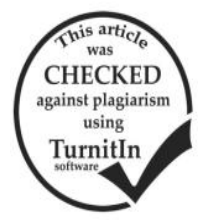

\begin{abstract}
This work aimed to investigate the effect of supplementing different forms of linseed (meal, whole linseed and oil) to lactating cow's ration on milk yield and milk composition .Sixteen multifarious Friesian cows $15 \pm 2.26 \mathrm{~kg}$ milk $/ \mathrm{d}$, and averaging $460 \pm 15.26 \mathrm{~kg} /$ body weight, were divided into four experimental feeding groups (4 each) for 180 days. All group animals were received concentrate feed mixture containing zero, linseed meal, whole linseed and oil linseed in ration A, B, C and D, respectively. All experimental rations were almost equals in energy and protein. Results indicated that supplementation of linseed meal recorded the highest FCM $(13.60 \mathrm{~kg} / \mathrm{h}$./d.). There were no significant differences in milk composition among groups. Supplementation linseed oil (D) reduced the apparent digestibility of CF compared with control. The different form of oil seed did not influence ruminal $\mathrm{pH}$ but it caused significant $(\mathrm{P}<0.05)$ increased in ruminal ammonia concentrations for $(\mathrm{C})$ and (D) groups compared with control. While, the concentration of volatile fatty acids was significantly $(\mathrm{P}<0.05)$ differ for cows fed (B) and (D) except those fed rations (C) compared with control . From the previous results, it could be concluded that using linseeds, especially meal, in lactating cow's rations increased milk yield decreased feed cost and give more profit per Kg milk without adverse effects on cow's health or performance.
\end{abstract}

Keywords: Oilseeds, rumen fermentation, digestibility, lactating cow.

\section{INTRODUCTION}

linseed (Linum usitatissiumum) also known as linseed, is thought to be one of the world's oldest cultivated crops. The by-product remaining after oil extraction from linseed is a source of protein which used in livestock feeds, especially in the rations of ruminant animals. The seed and oil were also used in the past in livestock production for its medicinal properties, in particular for its functions as a laxative as well as for improving skin and hair quality.

Recently, it showed a renewed interest in using linseed and linseed oil in animal rations to alter the fatty acid composition of meat products and, therefore, provide functional health benefits for the consumer.

Over a few past decades interest in ruminant animal rations with various fat sources has increased Hess et al., (2008)Initially, the primary aim of fat addition to the ruminant's ration was to provide concentrated energy.Presently, the increase interest in fat utilization in ruminant nutrition is mainly a possibility to modify fatty acid composition of animal origin food products ,milk and meat,(Jan et.al.,2013). Traditional varieties forms of linseed,were used in dairy cows feeding are characterized by highly content of total fatty acids (over 50\%) specially, linolenic acid C18:3(53\% of total FA)(Chow, 1992)P18/6 and others healthy fatty acid profile. These fatty acids promotes increased n-3 fatty acids and conjugated linoleic acid (CLA) content in milk (Chilliardet.al,. 2007).

Feeding dairy cows a ration contained whole flax seeds(linseed), flax oil or rolled extruded linseed (meal) has beneficial effects on the fatty acids profile of cow's milk whereas, there was an increase in alpha-linolenic acid (ALA, conjugated linoleic acid (CLA) and the proportion of stearic acid relative to other saturated fatty acids, and there was decrease in the omega6/omega-3 ratio and the overall saturated fat content. These enhancements give consumers value-added foods with good sensory qualities and a healthier fat profile
(Diane and Essi, 2008).Also, fat supplementation in the ruminant rations may have negative impact on rumen fermentation process, (Jenkins 1993). This impact depends on the amount of the inserted additive (Hess et al. 2008), its form, e.g. crude or processed (extruded, micronized) oilseeds (Gonthieret al. 2004and Doreauet al. 2009) and diet composition,mainly high roughage vs. high concentrate diets (Hess et al. 2008).

The aim of this study was to determine the effect of different physical forms of linseed fat on rumen parameter ,nutrients digestibility, milk yield and milk composition, beside its effect on rumen parameters.

\section{MATERIALS AND METHODS}

This experiment was carried out at El-Karada Experimental Station of Animal Production Research Institute belonging to Agriculture Research Center during summer season 2014-2015.

The aim of this study to use different sources of energy in concentrate feed mixtures for lactating cows. About ten percentage of energy source of concentrate feed mixture coming from Linseed meal, linseed and linseed oil were used as source of energy.

The composition of concentrate feed mixtures used in this experiment are shown in table (1)

Sixteen friesian cows average $460 \pm 15.26$ $\mathrm{kg} /$ body weight, were chosen and divided into four similar experimental feeding groups (4 in each). Animals in all of the experimental groups were housed under open loose system barns. The groups of animals were randomly assigned to receive four experimental ration containing concentrate feed mixtures which included zero $\%, 9 \%$ linseed meal , 6\% whole linseed and 3\% linseed oil as a source of energy . Energy coming from the previous materials were represent about $10 \%$ from total energy of concentrate feed mixtures . All animals received concentrate feed mixture plus roughage with rate of 50:50 according NRC (2001). The roughages were berseem hay and 
straw with rate of 1:2 concentrate feed mixtures were offered to animals at 8.00 a.m and 3:00 p.m followed by berseem hay while rice straw was available all day. All experimental rations were isonitrogenous and isoenergetic. The feeding trial lested 180 days. During experimental trials, milk yield were determined and its composition were estimated.

Table 1. Ingredient of concentrate feed mixtures (CFM)containing different sources of energy.

\begin{tabular}{lcccc}
\hline & \multicolumn{4}{c}{ CFM of Experimental rations } \\
\hline Item & $\mathrm{A}$ & $\mathrm{B}$ & $\mathrm{C}$ & $\mathrm{D}$ \\
Crushed corn & 40 & 38 & 35 & 25 \\
Soybean meal & 6.5 & 3 & 4 & 4 \\
Wheat brain & 24 & 22 & 20 & 24 \\
Sunflower meal & 23 & 21.5 & 26.5 & 33 \\
Linseed meal & 0 & 9 & 0 & 0 \\
Whole linseed & 0 & 0 & 6 & 0 \\
Linseed oil & 0 & 0 & 0 & 3 \\
molasses & 3 & 3 & 5 & 7.5 \\
Na-cl salt & 1 & 1 & 1 & 1 \\
Limestone & 2 & 2 & 2 & 2 \\
Minerals mix. & 0.5 & 0.5 & 0.5 & 0.5 \\
\hline A:cont. B:
\end{tabular}

A: control. B: CFM Containing linseed meal.C: CFM Containing linseed. D: CFM Containing linseed oil.

\section{Digestibility trial and rumen parameters:-}

During the feeding trial, feces samples were collected for three successive days via bag technique from each animal to determine total tract apparent nutrient digestibility using acid insoluble ash (AIA) technique as internal marker according to Van- Keulen and young (1977)

Table 2. Chemical composition of concentrate feed mixtures containing linseed as whole seed, meal or oil as sources of energy, barseem hay and rice straw.

\begin{tabular}{|c|c|c|c|c|c|c|c|}
\hline \multirow[b]{2}{*}{ Items } & \multirow{2}{*}{ DM(\%) } & \multicolumn{5}{|c|}{$\begin{array}{c}\text { Chemical composition DM } \\
\text { basis }(\%)\end{array}$} & \multirow[b]{2}{*}{ OM(\%) } \\
\hline & & $\mathbf{C P}$ & $\mathbf{C F}$ & $\mathbf{E E}$ & NFE & ASH & \\
\hline $\begin{array}{l}\text { Barseem } \\
\text { hay }\end{array}$ & 88.93 & 12.17 & 29.07 & $2.7 \mathrm{z} 4$ & 42.45 & 13.57 & 86.43 \\
\hline \multirow{2}{*}{$\begin{array}{l}\text { Rice } \\
\text { straw } \\
\text { linseed }\end{array}$} & 92.11 & 4.05 & 39.89 & 1.50 & 41.61 & 12.95 & 87.05 \\
\hline & 93.04 & 18.29 & 42.16 & 27.30 & 8.55 & 3.70 & 96.30 \\
\hline $\begin{array}{l}\text { linseed } \\
\text { meal }\end{array}$ & 91.51 & 28.90 & 7.57 & 8.52 & 44.35 & 10.66 & 89.34 \\
\hline \multicolumn{8}{|c|}{ *Concentrate feed mixtures } \\
\hline A & 88.02 & 16.11 & 9.87 & 3.04 & 64.02 & 6.96 & 93.04 \\
\hline B & 88.02 & 16.75 & 9.69 & 3.25 & 63.28 & 7.03 & 92.97 \\
\hline $\mathrm{C}$ & 88.00 & 16.42 & 10.34 & 4.76 & 61.28 & 7.20 & 92.80 \\
\hline $\mathrm{D}$ & 88.10 & 16.85 & 11.75 & 4.93 & 61.64 & 4.83 & 95.17 \\
\hline
\end{tabular}

Also, ruminal fluid samples were collected at the end of the experiment using stomach tube before feeding then at 3 and 6 hrs. After feeding. Samples of rumen liquor, for each animal, were filtered through four layers of cheesecloth, and then ruminal $\mathrm{pH}$ was immediately recorded using digital $\mathrm{pH}$ meter then, samples were stored at $-20 \mathrm{C}$ for latter analyses.

Analytical procedures:

Representative samples of feed ingredients and feces were analyzed for DM, CP, EE, CF and ash according to A.O.A.C. (1995). Ruminal ammonia nitrogen (NH3-N) concentration was determined according to Conway (1957). Ruminal total volatile fatty acids (TVFA's) concentration were determined according to Warner (1964). Milk analysis was determined using milko scan (model 130 series - type 10900 FOSS electric - Denmark)

\section{Statistical analysis}

Data collected for lactation, digestibility trials and milk were subjected to statistical analysis as oneway analysis of variance using SAS (1999) according to the following model:

Yij $=\mu+\mathrm{Ti}+$ eij where:

$\mathrm{Yij}=$ the observation

$\mu=$ Over all mean

Ti $=$ Effect of treatment

eij $=$ Experimental error

While, data of rumen parameters were statistically analyzed as two-way analysis of variance according the following model:

Yijk $=\mu+\mathrm{Si}+\mathrm{Tj}+(\mathrm{ST}) \mathrm{ij}+$ eijk. Where:

Yijk $=$ the observation.

$\mu=$ overall means.

$\mathrm{Si}=$ effect of time of sampling.

$\mathrm{Tj}=$ effect treatment.

(ST)ij=effect of interaction between time of sampling and treatment.

eijk = Experimental error Duncan's multiple range test (Duncan, 1955) was used to separate means when the dietary treatment effect was significant $(\mathrm{P}<0.05)$.

\section{RESULTS AND DISCUSSION}

Data presented in table (2) showed the chemical composition of different concentrate feed mixtures of experimental rations beside berseem hay and rice straw. It could be noticed that the chemical composition of both berseem hay and rice straw were agree with those reported by Etman et.al., (2014). Different concentrate feed mixtures have nearly the same composition. Also, it could be noticed that, however different component of each CFM, but all of them having the same chemical composition as shown in table (2). The CP content ranged between 16.11 to $16.85 \%$ while EE ranged from 3.04 to 4.93 . It could be shown that CFM of ration D containing some higher $\mathrm{CP}, \mathrm{EE}, \mathrm{CF}$ than the others, getting somewhat higher OM content . Generally CFM containing linseed had the highest EE content as shown in Table (2). There results were agreement with the finding of Mirzaeiet.al., (2009).

Data presented in table (3) showed the daily feed intakes from all ingredient feeds and total DM intakes beside calculated composition of experimental rations, digestibility coefficients and nutritive values of different experimental rations. 
It could be noticed that the average daily feed intakes (Kg DM / head) were nearly equal in different experimental groups.

The same pervious phenomenon were showed with calculated composition of experimental rations. The CP contents reached $13.03,13.50,13.67$ and $13.40 \%$ for rations $\mathrm{A}, \mathrm{B}, \mathrm{C}$, and $\mathrm{D}$, respectively while CF contents were $22.15,21.68,21.28$ and $21.00 \%$ for respective rations, as shown in table (3).

On the other hand, the digestibility coefficients of all nutrients are shown in table (3), DM digestibility of ration $\mathrm{C}$ ( contain whole linseed) showed somewhat higher digestibility $(68.23 \%)$ with no significant difference. The difference in $\mathrm{CP}$ digestibility were significant, showing higher $(\mathrm{p}<0.05)$ with ration $\mathrm{B}$. But differences in $\mathrm{CP}$ digestibility between ration $\mathrm{A}$ and both of $\mathrm{C}$ and $\mathrm{D}$ were not significant. The EE digestibility showed the same significant with ration $\mathrm{A}$, $\mathrm{B}$ and $\mathrm{C}$ with ration $\mathrm{D}$ recorded the lowest significant. Data also showed that the difference in CF digestibility between ration $\mathrm{B}$ and $\mathrm{C}$ were not significant. The lowest $\mathrm{CF}$ digestibility obtained with ration $\mathrm{D}$.

The NFE digestibility showed the highest value with ration $B$ (75.31) compared with the others. In this respect the ration $\mathrm{D}$ (containing linseed oil ) appeared the highest OM digestibility (70.24\%).

Generally, ration B, C and D containing linseed meal, whole linseed and linseed oil, respectively had higher digestibility of all nutrients compared with the control ration $(\mathrm{A})$.

It could be noticed that ration $B$ and $C$ containing linseed meal or whole linseed had the higher $(\mathrm{p}<0.05)$ significant in all nutrient digestibility.

The nutritive values expressed as TDN recorded $61.49,67,32$, 66,53 and $63.41 \%$ for rations A, B , C and $\mathrm{D}$, respectively versus $8.79,9.56,9.39$ and 9.10 $\%$ as DCP for respective rations. The tested rations (ration B, C and D) containing different sources of linseed pictures appeared significantly $(p<0.05)$ higher in TDN and DCP as shown in table (3).

Data in Table (3) showed that there was no significant $(\mathrm{P}<0.05)$ differences among groups in $\mathrm{DMD}$, being $66.80,66.87,68.23$ and $66.90 \%$, for A, B, C and $\mathrm{D}$ respectively. These results are in agreement with findings of Gonthier, et al.,(2004) that supplementation raw or extruded flaxseed to dairy cow's ration by $12.5 \%$ (of DM) had no effect on ruminal digestion of DM .The OMD was significantly $(\mathrm{P}<0.05)$ increased by $2.4 \%$ when cows fed ration $\mathrm{D}$ compared with those fed $\mathrm{R} 1$, while there was insignificant $(\mathrm{P}<0.05)$ difference in OMD among $\mathrm{A}, \mathrm{B}$ and $\mathrm{C}$. These results were in agreement with findings of Gonthieret al. (2004) that diets with flaxseed improved post ruminal OM and total-tract OM digestibility (expressed as a percent of passage to duodenumand percent of intake, respectively) compared with control diet containing no flaxseed. Also, Schroederet al.,(2014) found greater total-tract OM digestibility when feeding different forms of flaxseed to Holstein steers compared with all physical forms of flaxseed The digestion coefficient of CF was significantly $(\mathrm{P}<0.05)$ decreased with feeding ration $\mathrm{D}$ compared with ration $\mathrm{A}$ being $62.05 \%$ and
$64.74 \%$, respectively . The decrease in CF digestibility may be due to the negative effect of oils on rumen microbes especially cellulatic bacteria. These results were agreement with findings of Schroeder et al.,(2014). Data in the same table showed that there was significant difference $(\mathrm{P}<0.05)$ in the digestibility of $\mathrm{CP}$ digestibility among groups. Crud protein digestibility's were greater $(\mathrm{P}<0.05)$ for cows fed the flaxseed meal diets than for those fed the control diet. The data were in agreement with the findings of Oriaset al. (2002) who reported higher small intestine protein digestibility for steers fed soybean-supplemented diets than for steers fed a control diet.

Table 3.The average daily feed intake, calculated composition and digestibility coefficient and nutritive values of different experimental rations.

\begin{tabular}{lcccc}
\hline \multicolumn{5}{c}{ Experimental rations } \\
Items & A & B & C & D \\
\hline Av. feed intake (kg DM/h) & & & \\
concentrate feed & 6.492 & 6.750 & 6.665 & 6.628 \\
mixture & & & & \\
Barseem hay & 2.164 & 2.250 & 2.220 & 2.209 \\
Rice straw & 4.327 & 4.501 & 4.447 & 4.419 \\
Total DM intake & 12.983 & 13.501 & 13.332 & 13.256 \\
Calculated composition of experimental rations \\
DM & 90.66 & 89.62 & 89.83 & 89.92 \\
CP & 13.03 & 13.50 & 13.67 & 13.40 \\
EE & 2.65 & 3.40 & 4.01 & 4.37 \\
CF & 22.15 & 21.68 & 21.28 & 21.00 \\
NFE & 47.14 & 49.30 & 48.92 & 48.79 \\
Digestibility coefficients of experimental rations \\
DM & 66.80 & 66.87 & 68.23 & 66.90 \\
OM & $68.57^{\mathrm{b}}$ & $69.69^{\mathrm{ab}}$ & $69.88^{\mathrm{ab}}$ & $70.24^{\mathrm{a}}$ \\
CP & $67.44^{\mathrm{b}}$ & $70.84^{\mathrm{a}}$ & $68.67^{\mathrm{ab}}$ & $67.93^{\mathrm{b}}$ \\
EE & $79.30^{\mathrm{a}}$ & $77.79^{\mathrm{a}}$ & $77.84^{\mathrm{a}}$ & $74.01^{\mathrm{b}}$ \\
CF & $64.74^{\mathrm{b}}$ & $67.72^{\mathrm{a}}$ & $66.56^{\mathrm{a}}$ & $62.05^{\mathrm{c}}$ \\
NFE & 47.14 & 49.30 & 48.92 & 48.79 \\
Nutritive values, \% & \multicolumn{4}{c}{} \\
TDN & $61.49^{\mathrm{d}}$ & $67.32^{\mathrm{a}}$ & $66.53^{\mathrm{b}}$ & $63.41^{\mathrm{c}}$ \\
DCP & $8.79^{\mathrm{c}}$ & $9.56^{\mathrm{a}}$ & $9.39^{\mathrm{ab}}$ & $9.10^{\mathrm{b}}$ \\
\hline
\end{tabular}

a,b and c: Means of different superscripts letter in the same raw are significant $(\mathrm{P}<0.05)$ different

There was insignificant difference $(\mathrm{P}<0.05)$ in the digestibility of $\mathrm{EE}$ among rations $\mathrm{A}, \mathrm{B}$ and $\mathrm{C}$ while, ration $\mathrm{D}$ appeared significantly $(\mathrm{P}<0.05)$ decreased in digestibility of $\mathrm{EE} \%$ by $6.67 \%$ compared with control one. This increase in EE digestibility in ration $\mathrm{B}$ and $\mathrm{C}$ may be due to that seeds and meal make a kind of protection for its content of oils and this make oil escape from rumen micro organisms and bypass to intestine and degraded by lipase enzymes(Brasket al.,2013).

Data in the same table showed that there was a significant $(\mathrm{P}<0.05)$ increase in digestibility of NFE when cows fed ration $\mathrm{B}$ or $\mathrm{C}$ compared with those fed ration $\mathrm{A}$. This increase may be due that adding linseed meal or oilseeds inhibited the cellulatic bacteria in the rumen meanwhile, the ruminal microorganisms more depended on the soluble carbohydrates as energy source (Hristov et al.,2009). 
On the other hand data indicates that there was a significant $(\mathrm{P}<0.05)$ improvement in the nutritive values expressed as TDN or DCP for ration B , C or D compared with ration $\mathrm{A}$. This improvement may be due to the highest digestion coefficient of nutrients in these groups.

\section{Daily milk yield and its composition :}

Data presented in table (4) revealed that the actual milk yields were $12.06,15.40,13.01$ and 12.76 $\mathrm{Kg}$ with animals fed rations $\mathrm{A}, \mathrm{B}, \mathrm{C}$ and $\mathrm{D}$, respectively. The corresponding values as FCM yield were $10.61,13.60,11.25$ and $11.38 \mathrm{Kg}$ for rations, respectivly.

Table 4. Average daily actual and fat corrected milk (FCM) yields and its compositions.

\begin{tabular}{lcccc}
\hline Items & A & B & C & D \\
\hline Av.Milk yield (Kg/head/day) & & & & \\
Av. Actual Milk yield & $12.06^{\mathrm{c}}$ & $15.40^{\mathrm{a}}$ & $13.01^{\mathrm{b}}$ & $12.76^{\mathrm{b}}$ \\
Av. 4\% FCM yield & $10.61^{\mathrm{b}}$ & $13.60^{\mathrm{a}}$ & $11.25^{\mathrm{b}}$ & $11.38^{\mathrm{b}}$ \\
Av. Milk composition and its yield & & & & \\
Fat\% & 3.21 & 3.22 & 3.10 & 3.28 \\
Fat yield(gm/cow/day) & 387 & 496 & 403 & 419 \\
Protein\% & 2.67 & 2.64 & 2.68 & 2.60 \\
Protein yield(gm/cow/day) & 322 & 407 & 349 & 332 \\
Lactose\% & 4.71 & 4.72 & 4.87 & 4.74 \\
Lactose yield(gm/cow/day) & 568 & 727 & 634 & 605 \\
Total solids\% & 11.30 & 11.27 & 11.22 & 11.28 \\
Total solids yield (gm/cow/ day) & 1363 & 1736 & 1459 & 1439 \\
Solids not fat\% & 8.09 & 8.05 & 8.12 & 8.00 \\
solids not fat yield(gm/cow/ day) & 976 & 1240 & 1056 & 1020 \\
\hline
\end{tabular}

a,b and c: Means of different superscripts letter in the same raw are significant $(\mathrm{P}<0.05)$ different

The results showed that the milk yield either actual or corrected milk appeared to significant $(\mathrm{P}<0.05)$ higher than the others as shown in table (4) Increasing milk yield and FCM yield with animals fed ration $\mathrm{B}$ might be due to increase energy content of this ration. The results were agreement with the finding of Depeters and Cant(1992) and Chilliardet al., (2001). They reported that increasing in milk yield might be attributed to feed animals as fat supplemented ration at mid or even late lactation period, while feed animals on rations supplemented high amount oil caused a drop in feed intake and therefore milk yield as recorded by Chilliardet al.,(2001)and Regoet al., (2003). They reported also negative effects on digestibility and rumen fermentation.

On the other hand, all component of milk composition showed no significant difference among different experimental rations. Fat, protein, Ts, SNF and lactose percentages and their yields were no significant affected by different experimental rations. However somewhat higher in fat percentage was recorded with animals fed ration $\mathrm{D}$ (containing linseed oil) while animals fed ration A tended to higher of protein and TS percentages .

The results were in agreement with those reported by AbuGhazaleh et.al.,(2007), Bu et.al.,(2007) and Chilliard et.al.,(2001)

\section{Feed utilization efficiency:}

Data presented in table (5) revealed the average daily feed intake, milk yield either actual or FCM and feed utilization efficiency.

The results showed that animals fed ration $\mathrm{B}$ containing linseed meal appeared to the best efficiency , recorded $0.877 \mathrm{Kg} \mathrm{DM} / \mathrm{Kg}$ milk yield. When feed utilization efficiency expressed as $\mathrm{Kg}$ TDN or DCP per $\mathrm{Kg}$ milk yield, it was the most also efficient, being 0.592 and $0.084 \mathrm{Kg}$, respectively .

Also, feed utilization efficiency with animals fed ration $\mathrm{B}$ recorded $0.993,0.668$ and $0.095 \mathrm{Kg} \mathrm{DM}$, TDN and DCP per Kg 4\% FCM , respectively.

Table 5. Average daily feed unit intake, actual and fat corrected milk (FCM) yields and feed utilization efficiency .

\begin{tabular}{lcccc}
\hline \multicolumn{5}{c}{ Experimental rations } \\
& A & B & C & D \\
\hline Items & 4 & 4 & 4 & 4 \\
No. animals & 457 & 463 & 473 & 444 \\
Av. Live body weight (Kg) & 180 & 180 & 180 & 180 \\
Experimental period (day) & 12.06 & 15.40 & 13.01 & 12.76 \\
Av.Milk yield (Kg/head /day) & $10.61^{\text {b }}$ & $13.60^{\mathrm{a}}$ & $11.25^{\mathrm{b}}$ & $11.38^{\mathrm{b}}$ \\
Av. 4\% FCM yield (Kg /head/day) & 12.983 & 13.501 & 13.332 & 13.256 \\
Daily feed unit intake (Kg) & & & & \\
DM & 12.983 & 9.089 & 8.870 & 8.406 \\
TDN & 1.141 & 1.291 & 1.252 & 1.206 \\
DCP & & & & \\
Feed utilization efficiency as & & & & \\
Kg DM/ Kg milk yield & 1.077 & 0.877 & 1.025 & 1.039 \\
Kg TDN/ Kg milk yield & 0.662 & 0.592 & 0.682 & 0.659 \\
Kg DCP/ Kg milk yield & 0.095 & 0.084 & 0.096 & 0.095 \\
Kg DM/ Kg FCM yield & 1.224 & 0.994 & 1.185 & 1.165 \\
Kg TDN/ Kg FCM yield & 0.752 & 0.668 & 0.788 & 0.709 \\
Kg DCP/ Kg FCM yield & 0.108 & 0.095 & 0.111 & 0.106 \\
\hline
\end{tabular}

a,b and c: Means of different superscripts letter in the same raw are significant $(\mathrm{P}<0.05)$ different

It could be noticed that the most feed efficiency expressed as $\mathrm{Kg} \mathrm{DM} / \mathrm{Kg}$ milk yield was shown with animals fed ration $\mathrm{B}$ followed by those fed ration $\mathrm{C}, \mathrm{D}$ and $\mathrm{A}$.While feed efficiency expressed as $\mathrm{Kg} \mathrm{TDN} / \mathrm{Kg}$ milk yield were the best with animals fed ration $\mathrm{B}$ followed by those fed ration $\mathrm{D}$.

The same pervious trend was observed with feed efficiency when expressed as DM, TDN and DCP / Kg 4\% FCM yield, showing the ration B was the best efficiency followed by ration D . Generally experimental rations containing different pictures of linseed as a source of energy appeared to the best feed utilization efficiency it might be due to increasing nutritive values of those rations such as TDN and DCP $\%$ and also the animals fed these rations gave greater amounts of milk yield. These results were agreement with those reported by sabbahet.al.,(2012)

Data presented in Table (6) showed that the highest feed cost per head per day was recorded with group fed ration B (29.336 LE) versus the lowest feed cost for ration A (28.44 LE). At the same time, groups fed ration $B$ gave the highest milk yield with the highest cost of milk yield (61.600 LE) while groups fed ration $A$ gave the lowest milk yield with the lowest cost of milk yield (48.240 LE). So the animals fed ration B (containing linseed meal) showed the lowest feed cost 
to get one $\mathrm{Kg}$ both actual or 4\% FCM yield .According , animals of this group appeared to have the highest economical efficiency and gross margin above feed cost, being 2.100 and 1.998 respectively. The profit for $\mathrm{Kg}$ actual milk or 4\% FCM yield showed the highest profit, recording 2.095 and $2.372 \mathrm{LE}$, respectively. Moreover, increasing in profit for $\mathrm{Kg}$ milk either actual or $4 \% \mathrm{FCM}$ yield was significantly $(\mathrm{p}<0.05)$ higher than those of the others.

Generally animals fed ration fed ration B (containing linseed meal) had the highest milk yield, giving the highest net revenue with more net profit per both actual $\mathrm{Kg}$ milk and fat corrected milk yield.

Also, using linseed meal as source of energy in rations such as whole linseed or linseed oil did not significantly affected in feed cost or gross margin above feed cost and net revenue.

Table 6. Average daily fed intake as feed, milk yield, feed cost and economical efficiency with different experimental rations.

\begin{tabular}{|c|c|c|c|c|}
\hline \multirow[b]{2}{*}{ Items } & \multicolumn{4}{|c|}{ Experimental ration } \\
\hline & $\mathbf{A}$ & B & $\mathbf{C}$ & D \\
\hline \multicolumn{5}{|l|}{$\begin{array}{l}\text { Av. Daily feed intake as fed } \\
\text { (Kg/head/day) }\end{array}$} \\
\hline Concentrate feed mixture & 7.285 & 7.651 & 7.574 & 7.523 \\
\hline Berseem hay & 2.433 & 2.530 & 2.496 & 2.484 \\
\hline Wheat straw & 4.698 & 4.887 & 4.828 & 4.498 \\
\hline \multicolumn{5}{|l|}{ Av.Milk yield (Kg/head/day) } \\
\hline Av. Actual Milk yield & 12.06 & 15.40 & 13.01 & 12.76 \\
\hline Av. 4\% FCM yield & $10.61^{\mathrm{b}}$ & $13.60^{\mathrm{a}}$ & $11.25^{\mathrm{b}}$ & $11.38^{\mathrm{b}}$ \\
\hline \multicolumn{5}{|c|}{ Feed cost and economical efficiency } \\
\hline Cost of feed intake (LE/ h) & 28.440 & 29.336 & 28.990 & 29.022 \\
\hline Cost of milk yield(LE/ h) & 48.240 & 61.600 & 52.040 & 51.040 \\
\hline Av. Daily feed cost/ Kg milk yield & 2.358 & 1.905 & 2.228 & 2.274 \\
\hline Av. Daily feed cost $/ 4 \%$ FCM yield & 2.680 & 2.157 & 2.577 & 2.550 \\
\hline Av. Net revenue (LE/ h) & 19.800 & 32.264 & 23.050 & 22.018 \\
\hline Economical efficiency & 1.696 & 2.100 & 1.795 & 1.759 \\
\hline $\begin{array}{l}\text { Gross margin above feed } \\
\text { cost (LE) }\end{array}$ & 0.696 & 1.998 & 0.795 & 0.759 \\
\hline $\begin{array}{l}\text { Improvement in Economical } \\
\text { efficiency }\end{array}$ & - & 23.82 & 5.84 & 3.71 \\
\hline Profit / Kg milk yield & $1.642^{\mathrm{b}}$ & $2.095^{\mathrm{a}}$ & $1.772^{b}$ & $1.726^{\mathrm{b}}$ \\
\hline Profit / Kg 4\% yield & $1.866^{\mathrm{b}}$ & $2.372^{\mathrm{a}}$ & $2.049^{\mathrm{b}}$ & $1.935^{b}$ \\
\hline \multicolumn{5}{|c|}{$\begin{array}{l}\text { a,b and c: Means of different superscripts letter in the same raw } \\
\text { are significant }(P<0.05) \text { different } \\
\text { * Based on the assumption that price of one ton of berseem hay, } \\
\text { rice straw, concentrate feed mixture of ration } \mathrm{A}, \mathrm{B}, \mathrm{C} \text { and } \mathrm{D} \\
\text { was } 1600,700,2918,2858,2854 \text { and } 2911 \mathrm{LE}, \text { respectively } \\
\text { and the price of one } \mathrm{Kg} \text { of milk yield in selling was } 4.00 \mathrm{LE}\end{array}$} \\
\hline
\end{tabular}

\section{Rumen parameters}

Rumen parameters such as $\mathrm{pH}, \mathrm{NH} 3-\mathrm{N}$ and VFA's, concentration during different periods are presented in Table (7).

It could be showed that the overall means of rumen of $\mathrm{pH}$ values were $5.79,5.73,5.74$ and 5.77 of rumen of animals fed ration $\mathrm{A}, \mathrm{B}, \mathrm{C}$ and $\mathrm{D}$, respectively.

$\mathrm{PH}$ value tended to increase with sampling time at $3 \mathrm{hr}$ and decreased at $6 \mathrm{hr}$ except for such of group fed ration $\mathrm{A}$.

Data in table (5) showed that there was no significant $(\mathrm{P}<0.05)$ differences in the mean of ruminal $\mathrm{pH}$ among the experimental feeding groups .This may be due to the relatively low inclusion levels of flaxseed in the diet $(10 \%$ of diet DM). These results are agreement with findings of Schroeder et al., (2014).

The results obtained in Table (7) showed that the animals fed ration $\mathrm{C}$ (containing whole linseed) had the highest significant ammonia- nitrogen (NH3N)concentration (19.07) compared with the others. However, differences in NH3-Nbetween animals fed ration $\mathrm{A}$ and $\mathrm{B}$ were not significant.

Data in the same table indicated that there was a significant $(\mathrm{P}<0.05)$ increase of the mean of ruminal ammonia concentration in the rumen of cows fed $\mathrm{C}$ or D compared with those fed A, while, feeding cow ration $\mathrm{B}$ significantly $(\mathrm{P}<0.05)$ decreased ruminal ammonia concentration compared with $\mathrm{A}$. These results were agreement with the findings of Ueda et al., (2003) who observed the greater ruminal ammonia concentration in LO-supplemented dairy cows when compared with control cows. Other studies, reported a decrease in ammonia concentration in sheep supplemented with different levels of LO (Ikwuegbu and Sutton, 1982and Broudiscou et al., 1994).

Table7.Effect of feeding the experimental rations and rumen sampling time on some of rumen parameters of dairy cows.

\begin{tabular}{|c|c|c|c|c|c|}
\hline \multirow{2}{*}{ Item } & \multirow{2}{*}{$\begin{array}{c}\text { Sampling } \\
\text { time, h. }\end{array}$} & \multicolumn{4}{|c|}{ The Experimental rations } \\
\hline & & $\mathbf{A}$ & B & $\mathbf{C}$ & D \\
\hline \multirow{4}{*}{$\mathrm{pH}$} & 0 & 5.80 & 5.69 & 5.70 & 5.68 \\
\hline & 3 & $5.64^{\mathrm{bc}}$ & $5.76^{\mathrm{abc}}$ & $5.90^{\mathrm{ab}}$ & $5.86^{\mathrm{abc}}$ \\
\hline & 6 & $5.93^{\mathrm{a}}$ & $5.74^{\mathrm{abc}}$ & $5.62^{c}$ & $5.79^{\mathrm{abc}}$ \\
\hline & Mean & 5.79 & 5.73 & 5.74 & 5.77 \\
\hline \multirow{4}{*}{$\begin{array}{l}\text { NH3-N } \\
\text { mg/100 } \\
\text { ml R.L. }\end{array}$} & 0 & $14.37^{\mathrm{d}}$ & $14.95^{\mathrm{de}}$ & $19.24^{\mathrm{a}}$ & $10.46^{\mathrm{bc}}$ \\
\hline & 3 & $14.64^{\mathrm{de}}$ & $14.09^{\mathrm{e}}$ & $18.67^{\mathrm{a}}$ & $15.65^{\mathrm{c}}$ \\
\hline & 6 & $14.82^{\mathrm{de}}$ & $13.37^{\mathrm{e}}$ & $19.31^{\mathrm{a}}$ & $16.12^{b}$ \\
\hline & Mean & $14.61^{\mathrm{c}}$ & $14.14^{\mathrm{d}}$ & $19.07^{\mathrm{a}}$ & $16.08^{b}$ \\
\hline \multirow{4}{*}{$\begin{array}{l}\text { VFA's, } \\
\text { meq/100 } \\
\text { ml R.L. }\end{array}$} & 0 & $6.86^{\mathrm{bcd}}$ & $6.25^{\mathrm{bcd}}$ & $8.87^{\mathrm{ab}}$ & $6.44^{\mathrm{d}}$ \\
\hline & 3 & $9.88^{\mathrm{a}}$ & $7.40^{\mathrm{bcd}}$ & $8.23^{\mathrm{bc}}$ & $6.96^{\mathrm{bcd}}$ \\
\hline & 6 & $7.80^{\text {bcd }}$ & $7.62^{\text {bcd }}$ & $7.36^{\mathrm{bcd}}$ & $6.37^{\mathrm{bc}}$ \\
\hline & Mean & $8.18^{\mathrm{a}}$ & $7.09^{\mathrm{b}}$ & $8.15^{\mathrm{a}}$ & $6.59^{b}$ \\
\hline
\end{tabular}

a,b and c: Means of different superscripts letter in the same raw are significant $(\mathrm{P}<0.05)$ different

Data in Table (7) revealed that the VFA's, concentration showed somewhat higher with animals fed ration $\mathrm{A}$ and $\mathrm{C}$ compared with those fed ration $\mathrm{B}$ and D.

It could be found that the differences in VFA's, concentration between ration $\mathrm{A}$ and $\mathrm{C}$ and between ration $\mathrm{B}$ and $\mathrm{D}$ were not significant

There was no significant $(\mathrm{P}<0.05)$ difference of the mean of ruminal VFA concentration among cows fed ration $A$ and $C$, while, it was significant $(P<0.05)$ decrease for $\mathrm{B}$ and $\mathrm{D}$ by $13.32 \%$ and 19.43 , respectively compared with control, this depression may be due to the addition of fat partially replaces the nonstructural carbohydrates in the feed and so reduces the fermentable carbohydrate available for VFA production, which results in a decrease in the total VFA concentration in the rumen. This result agreed with the finding of (Chichlowski et al., 2005). These results were agreement with those reported by Brask 
et.al.,(2013), Broudiscou et.al.,(1994) and Mirzaei et.al.,(2009)

Data revealed that animals fed linseed as source of energy as different picture did not affected on some ruminal parameter.

Generally, Using linseed as source of energy with different picture tended to increase TDN and DCP. Using linseed meal in ration formulation of dairy cows increased milk yield, improved milk component, decreased feed cost and gave the most feed efficiency with the most highest profit per $\mathrm{Kg}$ milk yield.

\section{REFRANCE}

A.O.A.C.(1995) Methods of Analysis. Vol. 1: Agricultural Chemicals, Contaminats , Drugs. 16th ed. Washington, D.C. USA.

AbuGhazaleh, A. A., and L. D. Holmes.(2007).Diet supplementationwith fish oil and sunflower oil to increase conjugated linoleic acidlevels in milk fat of partially grazing dairy cows. J. Dairy Sci.90:2897-2904.

AbuGhazaleh, A. A., D. J. Schingoethe, A. R. Hippen, and K. F. Kalscheur. (2002). Feeding fish meal and extruded soybeans enhances the conjugated linoleic acid content of milk. J. Dairy Sci. 85:624-631.

Brask, M. , P. Lund, M. R. Weisbjerg, A. L. F. Hellwing, M. Poulsen, M. K. Larsen, and T. Hvelplund (2013).Methane production and digestion of different physicalforms of rapeseed as fat supplements in dairy cows J. Dairy Sci. 96 :2356-2365.

Broudiscou, L.; S. Pochet; and C. Poncet.(1994).Effect of linseed oilsupplementation on feed degradation and microbial synthesis in the rumen of ciliate-free and refaunated sheep. Anim. Feed Sci.Technol. 49:189-202.

Bu, D. P., J. Q. Wang, T. R. Dhiman, and S. J. Liu.(2007).Effectiveness of oils rich in linoleic and linolenic acids to enhance conjugatedlinoleic acid in milk from dairy cows. J. Dairy Sci. 90:998-1007.

Chichlowski, M. W; J.W. Schroeder, C.S. Park; W.L. Keller and D.E. Schimek (2005).Altering the fatty acids in milk fat by including canola seed in dairy cattle diets. J. Dairy Sci. 88: 3084.

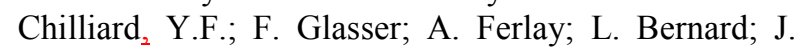
Rouel; M. Doreau. (2007). Diet, rumen biohydrogenation and nutritional quality of cow and goat milk fat: A review. Eur. J. Lipid Sci.Tec. 109, 828-855.

Chilliard, Y., A. Ferlay and M. Doreau (2001).Effect of different types of forages, animal fat or marine oils in cow's diet on milk fat secretion and composition, especially conjugated linoleic acid (CLA) and polyunsaturated fatty acids. Livestock Production Science, 70:31.
Chilliard, Y.; A. Ferlay; J. Rouel, and G. Lamberet.(2003) A reviewof nutritional and physiological factors affecting goat milk lipidsynthesis and lipolysis. J. Dairy Sci. 86:1751-1770.

Chow, C. K. (1992) Fatty Acids in Food and Their Health Implications. Marcel Dekker, New York, NY.

Conway, E.H. (1957). Micro diffusion analysis and volumetric error.5th Ed. Crosby Lockwood and Sons Ltd., London.

DePeters, E. J. and J. P. Cant. (1992). Nutritional factors influencing the nitrogen composition of bovine milk: A review. J. Dairy Sci. 75:2043.

Diane, H. M. and H. E. Essi (2008).Linseed in the ruminant diet, Adding linseed to feed enhances the fat profile of milk. Flax Council of Canada, Rev.

Doreau, M.; E. Aurousseau; C. Martin (2009). Effects of linseed lipids fed as rolled seeds, extruded seeds or oil on organic matter and crude protein digestion in cows. Anim. Feed Sci. Technol. 150, 187-196.

Duncan, D. B. (1955). Multiple ranges and multiple F test. Biometrics, 11:1-20.

Etman, K. E. I.; T.I. El Monayer,; S.K. Sayed; F. A. ElSayed and Mona E. Farag(2014). Effect of feeding different level of DDGS as a source of energy on sheep performance. J. Animal and Poultry Prod., Mansoura Univ., vol.5(2):27-41.

Gonthier, C.; A. F. Mustafa; R. Berthiaume; H.V.Petit; R. Martineau ; D.R.Ouellet (2004). Effects of feeding micronized and extruded flaxseed on ruminal fermentation and nutrient utilization by dairy cows. J. Dairy Sci. 87, 1854-1863.

Hess, B.W.;G.E. Moss; D.C. and Rule (2008). A decade of development in the area of fat supplementation research with beef cattle and sheep. J. Anim. Sci. 86: 188-204.

Hristov ,A.N.; M. Vander Pol ,M.; M. Agle ;S. Zaman ; C. Schneider ; P. Ndegwa ; V. K. Vaddella ;K. Johnson ; K. J. Shingfield and S. K. R. Karnati (2009) Effect of lauric acid and coconut oil on ruminal Fermentation, digestion, ammonia losses from manure, and milk fatty acid composition in lactating cows. J. Dairy Sci. $92: 5561$

Ikwuegbu, O. A., and J. D. Sutton.(1982). The effect of varying theamount of linseed oil supplementation on rumen metabolism in sheep. Br. J. Nutr. 48:365-375.

Jan, M.; K. Renata ; K. Edyta and B. Maciej (2013).Effect of the variety of linseed and its form (rolled or extruded) in dairy cow diets on nutrient digestibility. AnnalesUniversitatisMariae Curie-Sklodowska - Polonia, Vol. (2) Sectio EE.

Jenkins, T.C., (1993). Symposium: advances in ruminant lipid metabolism. Lipid metabolism in the rumen. J. Dairy Sci. 76, 3851-3863. 
Mirzaei, F. ; M. Rezaeian; A. Towhidi; A. Nik-khah and H. Sereshti (2009). Effects of fish oil, safflower oil and monensin supplementation on performance, rumen fermentation parameters and plasma metabolites in Chall sheep. Int.J.Vet.Res. 3, 2:113.

NRC. (2001). Nutrient Requirements of Dairy Cattle. National Academy Press, Washington, DC.

Nudda, A.; G. Battacone; R. Bencini, and G. Pulina.(2004).Nutritionand milk quality.Chapter 8.P129-149 in Dairy Sheep Nut.G.Pulina, ed. CABI Publishing, Wallingford, UK.

Orias, F.; C. G. Aldrich; J. C. Elizalde; L. L. Bauer, and N. R. Merchen. (2002). The effects of dry extrusion temperature of whole soybeans on digestion of protein and amino acids by steers. J. Anim. Sci.80:2493-2501.

Rex, N.(2015). Flax feed industry guide(review article). Flax Canada, Canadian International Grains Institute, P19.

Rego, O. A.; H. J. D. Rosa; P. Portugal; T. Franco; C. M. Vouzela; A. E. S. Borba, and R. J. B. Bessa. (2003). The effects of supplementationwith sunflower and soybean oils on the fatty acid profile of milkfat from grazing dairy cows. Anim. Res. 54:17-24.

SAS(1999). Statistical Analysis System SAS User,s Guide Statistics SAS Institute Inc. Editors, Cary, NC.
Sabbah M. Allam; M.A. Ali; Alaa H. Mohamed ;Haiam, A.Sayed (2012).Impact of Different Forms of Oils on Lactation Performance and Conjugated - Linoleic Acid Content in Goat Milk Egyptian J. Nutrition and Feeds . 10 (1):111.-7тา.

Schroeder , J. W. ; M. L. Bauer, and N. R. Bork. (2014).Effect of flaxseed physical form on digestibility of lactation diets fed to Holstein steers. J. Dairy Sci. 97 :5718-5728.

Shingfield, K. J.; C. K. Reynolds; G. Herva' s; J. M. Griinari; A. S.Grandison, and D. E. Beever. (2006).Examination of the persistencyof milk fatty acid composition responses to fish oil andsunflower oil in the diet of dairy cows. J. Dairy Sci. 89:714-732.

Ueda, K.; A. Ferlay; J. Chabrot; J. J. Loor; Y. Chilliard, and M.Doreau. (2003).Effect of linseed oil supplementation on ruminaldigestion in dairy cows fed diets with different forage: concentrate ratios . J. Dairy Sci. 86:3999-4007.

Van- Keulen, J.and B.A. Young (1977).Evaluation of acid-insoluble ash as neutral marker in ruminant digestibility studies.J . Anim. Sci.,44:282.

Warner, A.C.I. (1964) Production of volatile fatty acid in the rumen 1: Method of measurement .Nutr. Abstr. Review, 34:339.

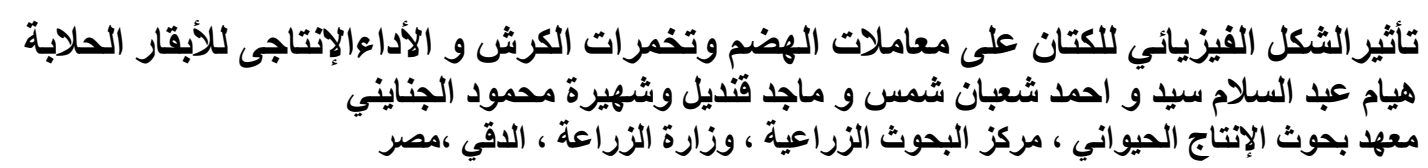

تهدف هذة الدر اسة الى دراسة تأثير أضافة أشكال مختلفة من الكتان (كسب او بذرة او زيت) الى علانئق الابقار الحلابة كمصدر للطاقة

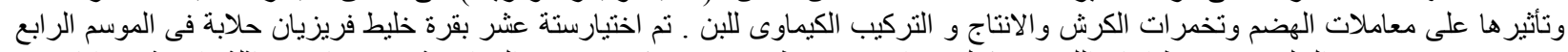

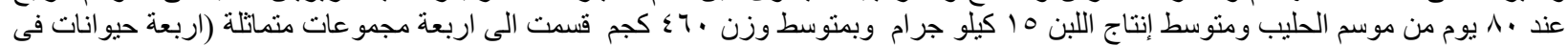

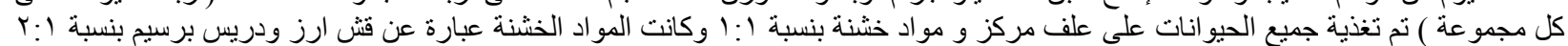

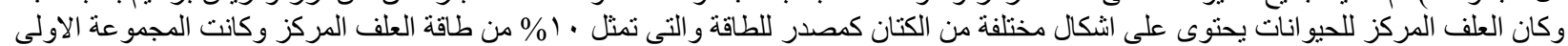

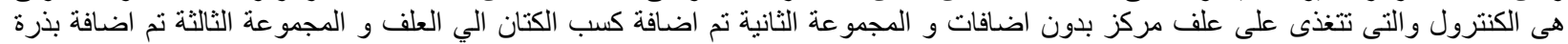

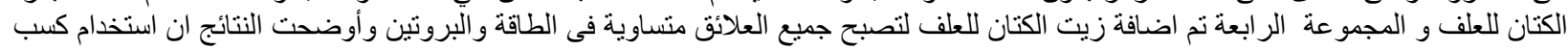

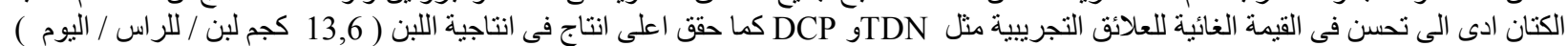

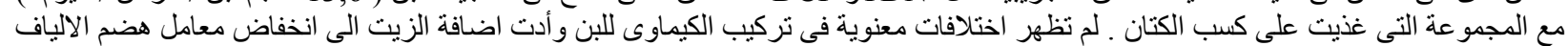

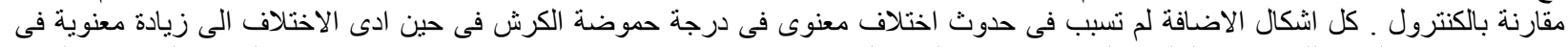

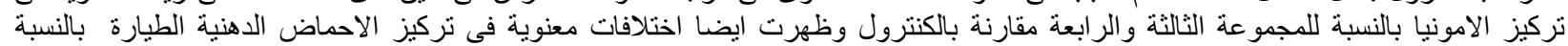

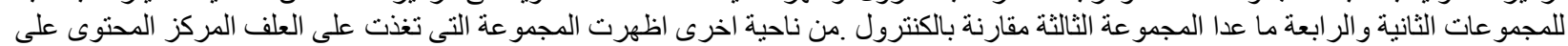

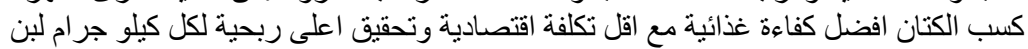

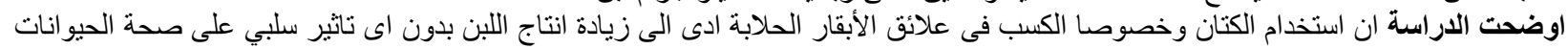
او كفاءتها الإنتاجية 